Ministry of Education State Scholarship scheme in the academic year $1961-62$, was $£ 23 \cdot 1$ million, or $£ 29 \cdot 3$ million gross before deductions were made for assessed contributions by students and their friends. For 1962-63 the corresponding figures were $£ 28.6$ million and $£ 35.3$ million, and for 1963-64, £31.5 million and $£ 39.3$ million. The estimated expenditure by local education authorities on maintenance allowances for school pupils over compulsory school age in $1964-65$ was $£ 1 \cdot 3$ million.

\section{Medical Education}

IN a statement in the House of Commons on June 29, the Prime Minister said that the Queen had approved the recommendation that a Royal Commission on Medical Education should be appointed with the following terms of reference: To review medical education, undergraduate and postgraduate, in Great Britain and in the light of national needs and resources, including technical assistance overseas, to advise the Government on what principles, future development, including its planning and co-ordination, should be based. In particular, in the light of these principles, and having regard to the statutory functions of the General Medical Council and the current review by that Council of recent changes in the undergraduate curriculum, to consider what changes might be needed in the pattern, number, nature or location of the institutions providing medical education or in its general content and to report.

The Prime Minister said that the Queen had approved the appointment of Lord Todd as chairman, and the names of the other members would be announced later. The appointment of this Commission marked the importance which the Government attached to a fundamental review of the whole structure of medical education, its organization, content, and claims on resources. Meanwhile, the Government was reviewing the immediate measures which could be taken in the field of medical manpower, and the appointment of this Commission would not delay any action which needed to be taken as a result of this review. In reply to questions, Mr. Wilson added that while no decision as to new medical schools could be taken before the Royal Commission had reported, action could, of course, be taken on the immediate measures required without waiting for the Commission's report.

Following a similar Statement in the House of Lords on the same day, Lord Taylor added that Nottingham had been approved by the previous Government as the site of a new medical school, and an academic plan for that medical school had just been published; discussions would now proceed between the University there and the University Grants Commission. He also confirmed that although further medical schools could not immediately be created, it was not clear whether the best way of meeting the immediate need was by establishing moro medical schools or by increasing the intake of existing ones. He emphasized that the Government was carrying out a review now, without waiting for the Commission to report, on the immediate measures that could be taken in this field to increase the supply of medical students and doctors.

\section{Overseas Development and Service Bill}

IN moving the second reading of the Overseas Development and Service Bill in the House of Lords on July 1, Lord Taylor, the Parliamentary Under-Secretary of State for Commonwealth Relations and the Colonies, said that the Bill extended and developed the provisions of the Colonial Development and Welfare Acts of 1959 and 1963 and the Overseas Service Act of 1961, being concerned both with capital development and technical assistance. Under Clause 1, the Bill raised the ceiling on the amount which could be spent on Colonial development and welfare, and advanced the date by which the money could be spent for a further four years. Since its provisions overlap with the existing Act of 1963 , it provided for five years in all, from April 1, 1965, to March 31, 1970. A.s much of the money provided under the previous Act remained unspent, the total amount available in the new period would be $£ 95$ million in grants and $£ 40$ million in loans for dependent territories only, compared with $\mathfrak{E 6 8 . 5}$ million for grants and $£ 32$ million for loans in three years only, under the previous Acts. The population of the dependent territories, however, had fallen from 18.75 million to 5.5 million as territories became independent. Under the previous Act the ratio of grants to loans was slightly more than $2: 1$, and this has now been increased so that 70 per cent of the aid available in the Bill would be by grants. These were considered to be more important than loans, as they do not put a further burden on the developing territories. Such sums would only be available for individual schemes within Colonial Development Plans, and under the main Act such Plans had to be approved by the Colonial Secretary, who consulted fully with the Minister for Overseas Development. Grants were available only towards the execution of plans which had first been approved; all the advisory services of the Ministry of Overseas Development could be brought to bear on the development problems of these territories.

Under Clause 2 the Overseas Service Act, 1961, was repealed and replaced, and the present Overseas Service Air Scheme was extended to cover people who were performing public or social services in overseas territories outside the Civil Services. Forty-one agreements have been signed under this Scheme, and at its peak more than 15,000 officers had been designated. More than 10,000 officers were still in posts under the Scheme in both independent and remaining dependent countries, of whom about 5,000 were members of the Overseas Civil Service, the rest being designated contract officers. Emphasis had been placed on maintaining, through a large number of short-term contracts, a considerable body of officers in the field to help overseas Governments to attain independence and to develop that independence as effectively as possible: the need for this help had not been reduced by independence. Although about 1,800 appointments were made under the Scheme in 1964, the vacancies outstanding at the end of the year exceeded the appointments made. With one major exception, the Government had not yet chosen the bodies to whom help (under the Scheme) should be offered, but it had begun a process of consultation so as to list a large number of bodies who might be eligible and then to assign some order of priority in the offers of help which could be made. It was estimated that the cost of this extension would rise to a maximum of about $£ 1.5$ million a year; the whole Scheme is at present costing the Government between $£ 15$ and $£ 16$ million a year.

\section{Mount John University Observatory, New Zealand}

The University of Pennsylvania, United States, and the University of Canterbury, New Zealand, formally opened the Mount John University Observatory, New Zealand, on July 10. The Observatory is the result of a joint project which began in 1961, and is situated at $3,500 \mathrm{ft}$. on the top of Mount John near Lake Tekapo in South Canterbury. It was, in fact, in limited operation before the official opening, and a 16-in. reflector telescope and an 8-in. refractor telescope lent by F. M. Bateson (a New Zealand research associate of the University of Pennsylvania) were operative. In use also was a 10.5-in. astrographic camera, which is utilized for taking pictures of large areas of the sky, and. which was originally installed in the University of Pennsylvania's old Cook Observatory at Wynnewood. Pennsylvania has sent a renovated and rebuilt 18-in. refractor telescope which was originally installed in the University's old Flower Observatory, Upper Darby. This telescope is being stored until a structure can be built to house it. The University also 